\title{
Atmospheric Pollution due to Road Traffic Case of the Greater Casablanca Region
}

\author{
HADER Khadija ${ }^{1}$ and Lahcen BAHI ${ }^{2}$ \\ 1. Research Laboratory for the Quality of Air and the Water, Section of Environment, Mohammadia School of Engineers (EMI), B.P. \\ 765 Agdal, Rabat, Morocco \\ 2. The Director of the Centre Doctoral Studies and the Responsible of the Applied Geophysics Laboratory, the Engineering Geology, \\ and the Environment, Mohammadia School of Engineers (EMI), B.P. 765 Agdal, Rabat, Morocco
}

\begin{abstract}
In the Greater Casablanca, road transport is the second largest emissions source of gaseous pollutants and particles after the industry [1]. The emitters are mobile and include different categories of vehicles in circulation, in the road network of the region [2]. Air emissions from road transport considered in this study are the exhaust emissions from combustion of fuel during vehicle movement. This is mainly $\mathrm{SO}_{2}$ (sulfur dioxide), $\mathrm{NO}_{\mathrm{x}}$ (nitrogen oxides), $\mathrm{CO}$ (carbon monoxide), $\mathrm{CO}_{2}$ (carbon dioxide), $\mathrm{SP}$ (suspended particulate) [3], VOC (volatile organic compounds), benzene, lead $\mathrm{Pb}$ and cadmium. These emissions depend mainly on the technology of the vehicle (type, fuel, engine size, and age), the vehicle speed, the engine temperature and ambient temperature [4].
\end{abstract}

Key words: Atmospheric pollution, road traffic, $\mathrm{NO}_{2}, \mathrm{SO}_{2}, \mathrm{CO}$.

\section{Nomenclature}

$\begin{array}{ll}\text { RGC } & \text { The region of Greater Casablanca; } \\ \text { LS } & \text { Linear sources; } \\ \text { DRCR } & \text { Direction of roads and road traffic; } \\ \text { UDP } & \text { Urban displacement plan }\end{array}$

\section{Introduction}

The transport sector is an essential link in the development of national and regional economy [5]. However this sector, particularly road transport, weighs heavily in the overall assessment of the emissions of substances involved in air pollution. In this study we will get hold of the causes behind this kind of pollution, while studying the nature, type and concentration of each pollutant by (PREFECTURE/ MUNICIPALITY).

\section{Road Network of the Region of Greater}

The road network of the RGC is a relatively dense

Corresponding author: HADER Khadija, engineer, research fields: geographic information systems, the air quality, the water quality and medical waste. network which extends over $644 \mathrm{~km}$ long [6] distributed between:

- Highway: $64 \mathrm{~km}$

- National road: $103 \mathrm{~km}$

- Regional road: $70 \mathrm{~km}$

- Provincial road: 404 km

\section{Road Traffic of the RGC}

The estimation of air emissions associated with the linear sources in the region [7], is based on traffic counts for characterizing the intensity of the daily flow of the traffic on urban and interurban roads in the $\mathrm{RGC}$ for each type of vehicle.

\subsection{Interurban Road Traffic}

The results of traffic counts at the national interurban network and highway carried out continuously give at RGC:

- The annual average daily traffic of vehicles in all categories identified by 24 counting stations on national, regional and provincial roads located within the region. According to DRCR, about $70 \%$ of this traffic is due 
to light vehicles and $30 \%$ for heavyweight [8];

- The average daily traffic of light vehicles and heavyweight raised by 7 tollbooths Highway Casablanca-Settat and Highway Casablanca bypass.

The DRCR counts cover a network interurban about $334 \mathrm{~km}$ or $52 \%$ of the length of interurban road network of the RGC.

\subsection{Urban Road Traffic}

Urban traffic is the subject of the traffic counts by vehicle category performed in the major urban roads in the region as part of the study of UDP (Urban Displacement Plan) of the RGC [9].

- The results of the counts carried out over 24 hours allowed to observe that the traffic flowing from 22:00 to 6:00 represents 5\% of total daily traffic of the business day and $7 \%$ on Saturday.

- The results of the counts between 06:00 and 22:00 show that the traffic in the morning peak period ( $7: 30$ to $10: 30$ ) represents $21.1 \%$ of the volume of 24 hours to Tuesday, and $19.3 \%$ for Saturday.

Counts cover a network of approximately $292 \mathrm{~km}$, or $25 \%$ of the length of the avenues and boulevards of the RGC.

\section{Results}

The distribution of pollutants by prefecture and municipality [10]:

Table 1 Distribution of the emission of pollutants by prefecture/municipality.

\begin{tabular}{|c|c|c|c|c|c|c|c|c|}
\hline \multirow{2}{*}{ Prefecture/Municipality } & \multicolumn{2}{|l|}{$\mathrm{CO}_{2}$} & \multicolumn{2}{|l|}{$\mathrm{SO}_{2}$} & \multicolumn{2}{|l|}{$\mathrm{NO}_{\mathrm{X}}$} & \multicolumn{2}{|l|}{$\mathrm{CO}$} \\
\hline & t/year & $\%$ & t/year & $\%$ & t/year & $\%$ & t/year & $\%$ \\
\hline Casablanca-Anfa & 63,468 & $10,4 \%$ & 269 & $9 \%$ & 344 & $9 \%$ & 1,689 & $15 \%$ \\
\hline MersSultanElFida & 28,882 & $4,7 \%$ & 121 & $4 \%$ & 156 & $4 \%$ & 824 & $7 \%$ \\
\hline Ain SebaaHayMohammadi & 76,114 & $12,5 \%$ & 344 & $12 \%$ & 433 & $11 \%$ & 2,024 & $18 \%$ \\
\hline Hay hassani & 13,641 & $2,2 \%$ & 61 & $2 \%$ & 80 & $2 \%$ & 327 & $3 \%$ \\
\hline AinChock & 24,385 & $4,0 \%$ & 117 & $4 \%$ & 154 & $4 \%$ & 379 & $3 \%$ \\
\hline Sidi Bernoussi & 76,452 & $12,6 \%$ & 374 & $13 \%$ & 483 & $13 \%$ & 1,127 & $10 \%$ \\
\hline BenM’sick & 27,208 & $4,5 \%$ & 129 & $4 \%$ & 167 & $4 \%$ & 505 & $4 \%$ \\
\hline Moulay Rachid & 36,652 & $6,0 \%$ & 169 & $6 \%$ & 224 & $6 \%$ & 674 & $6 \%$ \\
\hline Pachlik Mechouar & 4,208 & $0,7 \%$ & 18 & $1 \%$ & 23 & $1 \%$ & 103 & $1 \%$ \\
\hline Sous-total Casablanca & 351,010 & $57,6 \%$ & 1,602 & $56 \%$ & 2,065 & $55 \%$ & 7,653 & $68 \%$ \\
\hline Mohammedia & 11,987 & $2,0 \%$ & 60 & $2 \%$ & 81 & $2 \%$ & 142 & $1 \%$ \\
\hline Ain harrouda & 12,620 & $2,1 \%$ & 61 & $2 \%$ & 79 & $2 \%$ & 230 & $2 \%$ \\
\hline Sidi moussa benali & 8,394 & $1,4 \%$ & 43 & $1 \%$ & 58 & $2 \%$ & 79 & $1 \%$ \\
\hline Sidi moussamajdoub & 6,991 & $1,1 \%$ & 36 & $1 \%$ & 48 & $1 \%$ & 66 & $1 \%$ \\
\hline Bniyakhlef & 16,533 & $2,7 \%$ & 85 & $3 \%$ & 113 & $3 \%$ & 172 & $2 \%$ \\
\hline Echellalate & 38,627 & $6,3 \%$ & 203 & $7 \%$ & 257 & $7 \%$ & 366 & $3 \%$ \\
\hline Sous-total Mohammedia & 95,153 & $15,6 \%$ & 488 & $17 \%$ & 635 & $17 \%$ & 1,055 & $9 \%$ \\
\hline Mediouna & 3,455 & $0,6 \%$ & 17 & $1 \%$ & 22 & $1 \%$ & 56 & $1 \%$ \\
\hline Tit Mellil & 4,358 & $0,7 \%$ & 21 & $1 \%$ & 27 & $1 \%$ & 81 & $1 \%$ \\
\hline Lahraouiyine & 9,268 & $1,5 \%$ & 48 & $2 \%$ & 57 & $2 \%$ & 139 & $1 \%$ \\
\hline Mejjatia-ouledtaleb & 15,809 & $2,6 \%$ & 77 & $3 \%$ & 101 & $3 \%$ & 263 & $2 \%$ \\
\hline Sidi hajaj-Oued hassar & 24,426 & $4,0 \%$ & 119 & $4 \%$ & 155 & $4 \%$ & 444 & $4 \%$ \\
\hline Soustotal Mediouna & 57,316 & $9,4 \%$ & 283 & $10 \%$ & 361 & $10 \%$ & 983 & $9 \%$ \\
\hline Bouskoura & 37,508 & $6,2 \%$ & 184 & $6 \%$ & 245 & $6 \%$ & 553 & $5 \%$ \\
\hline Dar Bouaza & 36,851 & $6,0 \%$ & 175 & $6 \%$ & 242 & $6 \%$ & 617 & $5 \%$ \\
\hline Nouacer & 12,617 & $2,1 \%$ & 60 & $2 \%$ & 90 & $2 \%$ & 165 & $1 \%$ \\
\hline OuledSalah & 18,721 & $3,1 \%$ & 89 & $3 \%$ & 130 & $3 \%$ & 241 & $2 \%$ \\
\hline Sous-total Nouaceur & 105,697 & $17,4 \%$ & 508 & $18 \%$ & 706 & $19 \%$ & $\mathbf{1 , 5 7 7}$ & $14 \%$ \\
\hline Total & 609,175 & $100,0 \%$ & 2,881 & $100 \%$ & 3,768 & $100 \%$ & 11,268 & $100 \%$ \\
\hline
\end{tabular}




\begin{tabular}{|c|c|c|c|c|c|c|c|c|}
\hline \multirow{2}{*}{ Prefecture/Municipality } & \multirow{2}{*}{$\frac{\text { MPS }}{\text { t/year }}$} & \multicolumn{3}{|c|}{$\mathrm{Pb}$} & \multicolumn{2}{|l|}{ Benzene } & \multicolumn{2}{|l|}{ VOC } \\
\hline & & $\%$ & $\mathrm{~kg} /$ year & $\%$ & $\mathrm{~kg} /$ year & $\%$ & $\mathrm{t} /$ year & $\%$ \\
\hline Casablanca-Anfa & 66 & $9 \%$ & 22,8 & $13,5 \%$ & 19889 & $15 \%$ & 399 & $14 \%$ \\
\hline MersSultanElFida & 31 & $4 \%$ & 10,6 & $6,3 \%$ & 11245 & $9 \%$ & 220 & $8 \%$ \\
\hline Ain SebaaHayMohammadi & 87 & $12 \%$ & 23,9 & $14,2 \%$ & 29405 & $22 \%$ & 602 & $21 \%$ \\
\hline Hay hassani & 16 & $2 \%$ & 4,3 & $2,6 \%$ & 3,788 & $3 \%$ & 95 & $3 \%$ \\
\hline AinChock & 29 & $4 \%$ & 6,5 & $3,9 \%$ & 4,040 & $3 \%$ & 97 & $3 \%$ \\
\hline Sidi Bernoussi & 91 & $13 \%$ & 19,1 & $11,3 \%$ & 11,694 & $9 \%$ & 269 & $9 \%$ \\
\hline BenM’sick & 32 & $5 \%$ & 7,5 & $4,5 \%$ & 6,947 & $5 \%$ & 142 & $5 \%$ \\
\hline Moulay Rachid & 42 & $6 \%$ & 10,9 & $6,5 \%$ & 8,628 & $7 \%$ & 179 & $6 \%$ \\
\hline PachlikMechouar & 4 & $1 \%$ & 1,4 & $0,8 \%$ & 1,088 & $1 \%$ & 23 & $1 \%$ \\
\hline Sous-Total Casablanca & 401 & $56 \%$ & 107,0 & $63,5 \%$ & 96,723 & $74 \%$ & 2,025 & $71 \%$ \\
\hline Mohammedia & 14 & $2 \%$ & 2,7 & $1,6 \%$ & 946 & $1 \%$ & 23 & $1 \%$ \\
\hline Ain harrouda & 15 & $2 \%$ & 3,3 & $2,0 \%$ & 2,896 & $2 \%$ & 62 & $2 \%$ \\
\hline Sidi moussa benali & 11 & $2 \%$ & 1,7 & $1,0 \%$ & 377 & $0 \%$ & 14 & $0 \%$ \\
\hline Sidi moussamajdoub & 9 & $1 \%$ & 1,4 & $0,9 \%$ & 314 & $0 \%$ & 12 & $0 \%$ \\
\hline Bniyakhlef & 20 & $3 \%$ & 3,4 & $2,0 \%$ & 823 & $1 \%$ & 26 & $1 \%$ \\
\hline Echellalate & 48 & $7 \%$ & 7,2 & $4,3 \%$ & 1,553 & $1 \%$ & 56 & $2 \%$ \\
\hline Sous-totalMohammedia & 117 & $16 \%$ & 19,8 & $11,7 \%$ & 6,907 & $5 \%$ & 193 & $7 \%$ \\
\hline Mediouna & 4 & $1 \%$ & 0,8 & $0,5 \%$ & 829 & $1 \%$ & 17 & $1 \%$ \\
\hline Tit Mellil & 5 & $1 \%$ & 1,1 & $0,7 \%$ & 1,184 & $1 \%$ & 24 & $1 \%$ \\
\hline Lahraouiyine & 11 & $2 \%$ & 1,8 & $1,1 \%$ & 1,792 & $1 \%$ & 37 & $1 \%$ \\
\hline Mejjatia-ouledtaleb & 20 & $3 \%$ & 3,9 & $2,3 \%$ & 3,855 & $3 \%$ & 79 & $3 \%$ \\
\hline Sidi hajaj - Oued hassar & 31 & $4 \%$ & 6,2 & $3,7 \%$ & 6,954 & $5 \%$ & 139 & $5 \%$ \\
\hline Sous-total Mediouna & 72 & $10 \%$ & 13,9 & $8,3 \%$ & 14,615 & $11 \%$ & 297 & $10 \%$ \\
\hline Bouskoura & 42 & $6 \%$ & 9,2 & $5,5 \%$ & 3,177 & $2 \%$ & 116 & $4 \%$ \\
\hline Dar Bouaza & 46 & $6 \%$ & 10,1 & $6,0 \%$ & 7,571 & $6 \%$ & 172 & $6 \%$ \\
\hline Nouacer & 14 & $2 \%$ & 3,4 & $2,0 \%$ & 838 & $1 \%$ & 21 & $1 \%$ \\
\hline OuledSalah & 20 & $3 \%$ & 5,1 & $3,0 \%$ & 937 & $1 \%$ & 26 & $1 \%$ \\
\hline Sous-totalNouaceur & 122 & $17 \%$ & 27,8 & $16,5 \%$ & 12,522 & $10 \%$ & 336 & $12 \%$ \\
\hline Total & 711 & $100 \%$ & 169 & $100,0 \%$ & 130,768 & $100 \%$ & 2,851 & $100 \%$ \\
\hline
\end{tabular}

\section{Discussion}

The road transport sector is the origin of the emissions from passenger cars and commercial vehicles in the first place. It is the main emitter of benzene and $\mathrm{CO}$, as he takes relatively large share in $\mathrm{NO}_{\mathrm{x}}$ emissions, VOC, MPS and $\mathrm{CO}_{2}$, and less important $\mathrm{SO}_{2}$ and heavy metals. A small share of emissions of VOCs in the road transport sector is due to evaporation of petrol in service stations. Ordinarily, road transport emissions depend on the type of fuel used and the age and speed of vehicles. Thus:

- The petrol vehicles emit more $\mathrm{NO}_{\mathrm{x}}, \mathrm{CO}$, VOC and diesel vehicles. Conversely, these emit more $\mathrm{SO}_{2}$ than gasoline vehicles;
- Only gasoline vehicles are the source of $\mathrm{Pb}$ emissions from road transport;

- $\mathrm{NO}_{\mathrm{x}}$ emissions increase with speed;

- Emissions of pollutants from road transport decrease with fleet renewal, represented by vehicles less polluting.

\section{Conclusion}

Emissions from road transport are largely rejected in territorial units characterized by a diffuse dense urban traffic and an important interurban traffic. This is the case of the prefectures of the districts of Casablanca-Anfa and Ain Sebaa-Hay Mohammadi, the prefecture of Mohammadia and Mediouna provinces and Nouacer [11]. 


\section{References}

[1] MEM (Ministry of energy, mines, water and environment, Department of Environment). March 2009. Air emissions inventory of the greatest Casablanca.

[2] Wilaya of greater Casablanca region, organizing authority for urban transport. October 2011. «traffic management».

[3] Diagnostic study on the evaluation of pollution due to fine particles and their constitution, integrating methods of bio-indication and bio-accumulation in Alsace «Convention $\mathrm{n}^{\circ}$ 2001.2.57.8005 of 09.10.2001». November 2001.

[4] Counsel of industrial and automotive experts of morocco «road safety, accidents and pollution». 27 January 2011.

[5] Wilaya of greater Casablanca region, April 2008. «Orientation of UDP in the field of public transport and traffic» sub-mission 3-3.

[6] The Economic and Social Development Plan of the Greatest Casablanca. 2014.
[7] Urban agency of Casablanca. June 2011. "Study of mobility plans and traffic".

[8] Brucher, W., Kessler, C., Kerschgens, M., and Ebel, A., 2000. "Simulation of Traffic-Induced Air Pollution on Regional to Local Scales."Atmospheric Environment 34 (27): 4675-81.

[9] Wilaya of greater Casablanca region. Organizing authority for urban transport. Février 2014. "Study of the traffic plan of the greater Casablanca region", mission report 6: elaboration of action plan. (provisional version)

[10] Dispersion modeling of atmospheric emissions of an industrial site. R.PERKINS, L.SOULHAC, P.MEJEAN, I. RIOS-LMFA-central school of Lyon. September 2005.

[11] Ministry of Territory Planning, of Water And Environment, Secretary of State Charge of The Environment, Direction of Monitoring And Risk Prevention, Service Air and national laboratory of environment. July 2002. «ATMOSPHERIC POLLUTION IN MOROCCO». 